\title{
CONSTRUCTION AND EVALUATION OF A VERTICAL MOTORIZED FEED MIXER
}

\author{
M. A. Adedeji ${ }^{*}$, T. A. Adegboye ${ }^{2}$, I. K. Adesina ${ }^{1}$, O. O. Ajayi ${ }^{2}$, N. A. Azeez ${ }^{2}$ \\ ${ }^{1}$ Department of Agricultural and Bio-Environmental Engineering Technology, Federal \\ Polytechnic, Ede, Osun State, Nigeria. \\ ${ }^{2}$ Department of Mechanical Engineering Technology, Federal Polytechnic, Ede, Osun State, \\ Nigeria.
}

*Corresponding Email: maadedeji@fptb.edu.ng; Tel: +234-7068154452

Cite this article:

Adedeji M. A., Adegboye T. A., Adesina I. K., Ajayi O. O., Azeez N. A. (2021),

Construction and Evaluation of a Vertical Motorized Feed Mixer. Advanced Journal of Science, Technology and Engineering 1(1), 27-41. DOI: 10.52589/AJSTE-UIXXE0N2.

\section{Manuscript History}

Received: 19 Oct 2021

Accepted: 9 Nov 2021

Published: 25 Nov 2021

Copyright $\odot 2020$ The Author(s). This is an Open Access article distributed under the terms of Creative Commons AttributionNonCommercial-NoDerivatives 4.0 International (CC BY-NC-ND 4.0), which permits anyone to share, use, reproduce and redistribute in any medium, provided the original author and source are credited.
ABSTRACT: In order to reduce the overall cost of poultry production by small scale farmers, a motorized feed mixer was modified, fabricated and evaluated. The mixer consists of an outer drum, an inner mixing chamber and an auger. All these components were vertically oriented for mixing operation. There was a hopper located at the base of the mixer for loading the materials and a chute for the discharging of mixed products. It was modified to work through a central rotating auger fixed on a shaft that carries a pulley of diameter $185 \mathrm{~mm}$. The rotational motion was transmitted from a motor through a V-belt to the pulley shaft. A 5-0 hp electric motor with $1440 \mathrm{rpm}$ was used to drive the machine. Mixing was achieved as the auger conveyed the feed materials from the bottom to the top, in a continuous rotational motion. The mixer was evaluated using a whole corn kernel (WCK) at $15.35 \%$ (d.b) and small pieces of coloured paper (CP) of $5 \times 5 \mathrm{~mm}^{2}$ as tracers in ground maize as base materials. The auger pitch was reduced from $90.0 \mathrm{~mm}$ to $85.0 \mathrm{~mm}$ to increase the number of pitches from 10 to 12. This modification increased the throughput capacity of the mixer from $50.0 \mathrm{~kg}$ to $70.0 \mathrm{~kg}$. The mixed material was delivered through the delivery chute after mixing. Mixing time values evaluated were 2.0, 4.0, 6.0, 8.0 and 10.0 mins. The test results showed that maximum mixing occurred at 6.0 mins for coloured paper and 8.0 mins for whole kernel corn.

KEYWORDS: Feed, mixer, throughput capacity, tracer, modification. 


\section{INTRODUCTION}

The livestock industry is important in the provision of food (milk, meat and eggs), clothing (wool), power (drought animals) and recreation. The industry is particularly important in the conversion of grains into grain by-products, posture lay and silage into products suitable for human consumption. About $75 \%$ of the cost of producing livestock are feed cost (Balami, et al., 2013; Kalu \& Chuwkuwonwe, 1986). It has been noted that proper feeding of livestock is a matter of supplying them with the right amount of those chemical elements and compounds essential for carrying on the different life processes. These elements and compounds are usually referred to as feed nutrients.

\section{Feed and Feedstuff}

From a nutritional standpoint, feeds can be classified into five (5) major groups:

- Roughage

- Energy and basal feeds

- Protein concentrates or supplements

- Mineral and vitamin supplements

- Non-nutritive feedstuffs or feed additions.

All of these ingredients mentioned above and those ingredients of other livestock are in solid form and must be ground and mixed (Monison \& Monison, 1980) for the following reasons:

\section{Increase in palatability of the feed:}

This is essentially the result of a sum total of appearance, odour, taste, texture, temperature and auditory properties of the feed sensed by the animal in the process of locating and consuming feed.

\section{Simplify mixing of different ingredients:}

Unit mixing of coarse, fine, and granular material with various fibre, protein and fat contents is much easier if ground. In view of the economic factors related to ownership of feed grinders and cost of production, peasant farmers (or small scale poultry farmers) for whom this research is purposefully designed are advised to have their ingredients ground manually (e.g., pounding) or mechanically (e.g., by milling). The capacity of the intended mixer is for small-scale poultry farmers (Dogo, 2001).

\section{Importance of Feeds}

A regular supply of feed to farm animals is very essential to the health and productive life of the farm livestock. Feed, like food, has its importance on livestock growth and on the development of their skeleton, muscles, flesh, feathers and so on for the nutritive and healthy production of eggs, meat, milk and fat of an excellent quantity and quality for human needs. The requirements for these various nutrients, as stated by Diarra et al. (2001), in any feeding programme are usually composite since the programmes may be practically needed to accomplish some vital functions. 


\section{Mixing Problems}

The next operation in feed preparation is feed mixing. Mixing is very essential since concentrates contain different feed ingredients. But for the purpose of this research, it is limited to the mixing of ground maize, soya beans, rice bran, maize bran and fish meal. The mixing process can be achieved by lifting the materials continually up and down in mass from the bottom of the feeding chamber or hopper and pouring them back into the feeder. A satisfactory mix is then obtained in the process with a uniform mixture in a minimum time and with a minimum cost for overhead power and labour.

\section{Theory of Solid Mixing}

It is not possible to obtain a completely uniform mixture of dry particulate solids. The degree of mixing achieved depends on the following:

- $\quad$ The efficiency of the materials to aggregate

- $\quad$ The tendency of the materials to aggregate

- $\quad$ The moisture content, surface characteristics and flows of each component.

Generally, materials that are similar in size, shape and density can form a material. During the mixing of the component, the uniformity of the resulting product depends on the equilibrium achieved between the mechanisms of mixing and unmixing which is in turn related to the type of mixer, operating conditions and the components. In some mixtures, uniformity is achieved after a given period and then un-mixing begins. Accurate timing of the mixing aspiration becomes important in such cases (Diarra et al., 2001).

\section{Mixing Time}

It is not possible to predict precisely the best mixing interval for a specific feed mixture in a given mixer. Ear and Johnson (2007) evolve the notion that mixers of different designs do not necessarily perform identically and occasionally, mixers of the same design and manufacture were found to give different results.

\section{Convective Mixing}

This is the transport of groups of particles from one location in the mixture to another location.

\section{Diffusive Mixing}

This is the distribution of particles over a fleshy developed surface of the material.

\section{Shear Mixing}

This is the setting up of slip planes within a mixture. To some extent, this mechanism cannot completely separate all functions in a given process. Different mixers however show different predominating mechanisms. If power, which tends to segregate, is to be mixed, convective mixing is the mechanism that will lead to mixing with the least segregation. Asunda (2003) experimented on auger conveyors and reported the following factors affecting the throughput of auger conveyors: 


\section{Speed}

The peak of throughput is attained when the speed is in the region of $1000 \mathrm{rev} / \mathrm{min}$. Commercial augers in common use run at speeds between 1000-1200 rev/min for three inches auger and 500-700 rev/min for six inches.

\section{Pitch}

The test results generally confirm the suitability of the different pitches for the various duties. For general use, most commercial augers have a value of pitch/diameter approximately equal to one. For high capacity conveying of free-flowing material (e.g., dry grain), values of pitch/diameter approximately equal to 1.5 are also recommended.

\section{Moisture Content}

The result shows that while an increase in moisture content up to a value of $20 \%$ has a negligible effect on throughput, any increase of about $20 \%$ is likely to have a marked effect on the auger tested.

\section{Clearance}

The tests indicate that clearance at any size will reduce the throughput, although with one of $3 / 15$ inch, the drop was only $5-10 \%$ at a reasonable high speed at any elevation. Agbor (1996) designed and constructed a manually operated rotating shaft. The bevel gear arrangement provides the mixer with the driving mechanism. With the help of a bevel gear alignment, the motion attached to the gear is set in motion as the handle is rotated.

\section{MATERIALS AND METHODS}

\section{Mixer Components}

The mixing machine consists of parts dealing with the feeding, mixing and delivery.

The basic functional components include the following:

- Hopper: For feeding or temporary storage of the ingredients.

- Screw or auger conveyor: For lifting the materials from the upper end, thereby accomplishing mixing.

- Main body: Houses and supports the functional parts.

- Bearing: Supports and transmits loads.

- Belt and pulley: A belt is a flexible band used to connect pulleys that transmit motion and power. 


\section{Design Specifications}

\section{Hopper}

There are variations in the shapes of the hopper for this design; a semi-conical hopper is used due to the cylindrical shape of the part of the container to which it is attached and also for easy flow of material into the auger conveyor. It is made of a mild steel metal sheet of one millimetre thickness. The upper and lower ends diameter are $30 \mathrm{~mm}$ and $192.0 \mathrm{~mm}$ respectively with a height of $200.0 \mathrm{~mm}$.

\section{Auger Conveyor}

The auger is made from circular plates cut from galvanized metal sheets of $0.5 \mathrm{~mm}$ thickness. The external diameter is $188 \mathrm{~mm}$ while the internal diameter is $60.0 \mathrm{~mm}$. The circular plates are cut, shaped and welded to a galvanized steel pipe of $20 \mathrm{~mm}$ diameter. The pitch of the auger $(132.0 \mathrm{~mm})$ on the other shape is fitted to a pulley and the length of the auger is $1200.0 \mathrm{~mm}$.

\section{Main Frame}

This is designed in such a way that a frustum connects two cylinders. The upper cylinder is wider with a diameter of $450.0 \mathrm{~mm}$. The upper and lower diameters of the frustum are 450.0 $\mathrm{mm}$ and $1950 \mathrm{~mm}$ respectively. The hopper is welded on the lower cylinder and the delivery chute is attached to the frustum. They are all constructed of mild steel metal sheets of onemillimetre thickness (check isometric drawing at the back).

\section{Pillow Bearing}

This design made use of the rolling bearing (ball bearing because of their advantages over journal bearings particularly for the fact that they are suitable for very low speed). The ball bearing used is of bore diameter $20.0 \mathrm{~mm}$ and outside diameter $42.0 \mathrm{~mm}$.

\section{Shaft}

A shaft is a rotating member which transmits power. A transmission shaft is used in this design which receives its motion electrically via poultry and transmits it to the auger conveyor. The shaft is made of a mild steel rod of $20 \mathrm{~mm}$ diameter and length $1400.0 \mathrm{~mm}$.

\section{Design Calculations}

\section{Determination of Screw Conveyor}

According to Akpobi and Ovuworie (2008), the pitch of the screw conveyor can be determined using the formula:

$$
\begin{aligned}
& \mathrm{T}=(0.5 \text { to } 1.0) \mathrm{D} \\
& \text { where: } \\
& \mathrm{T}=\text { pitch of screw }(\mathrm{mm}) ; \mathrm{D}=\operatorname{screw} \text { diameter }(\mathrm{mm}) ; \mathrm{T}=(0.3)(188)=131.6=132.0
\end{aligned}
$$
$\mathrm{mm}$. 


\section{Determination of Screw Diameter}

The screw diameter is governed by the lump size being at least 12 times that of loads of uniform lump size and at least four times the maximum lump size in case of unsized bulk materials (Shiglry \& Mischike, 2001). In this design, the diameter of the screw is $188.0 \mathrm{~mm}$.

\section{Determination of Conveying Speed}

The nature of load and screw diameter and the intensity of abrasive action of the material govern the screw diameter. Conveyors handling heavy materials commonly operate at about $50 \mathrm{rpm}$ and they are designed to convey light loads at up to $150 \mathrm{rpm}$ (Klarmi \& Gupta, 2005).

The conveying speed of the screw conveyor is obtained from the formula:

$$
\mathrm{K}=\frac{t n}{60}
$$

where:

$\mathrm{t}=$ lead of screw $2 \times$ pitch; $\mathrm{n}=$ conveying speed $(\mathrm{m} / \mathrm{s})$

Using $\mathrm{t}=2(0.132)=0.264$

$$
\mathrm{n}=150 \mathrm{rpm} ; \mathrm{k}=\frac{(0,264)(150)}{60}=0.66 \mathrm{~m} / \mathrm{s}
$$

\section{Volume Determination of Screw Conveyor}

The volume of the screw conveyor per revolution, according to Klarmi and Gupta (2005), is given as:

$$
\mathrm{V}=\frac{D 2-d 2}{4}(n \times p)
$$

where: $\quad \mathrm{V}=$ Volume of screw conveyor/revolution $\left(\mathrm{m}^{3}\right) ; \quad \mathrm{D}=$ Diameter of screw $(\mathrm{m})$;

$$
\mathrm{D}=\text { pipe diameter }(\mathrm{m}) ; \quad \mathrm{p}=\text { Screw pitch }(\mathrm{m})
$$

$$
\text { Hence, } V=\frac{(0.188-0.02)(0.135)(3.142)}{4}=3.705 \mathrm{~mm}^{3}
$$

$\therefore$ Volume per revolution $=0.003705 \mathrm{~m}^{3}$

\section{Determination of the Conveyor Capacity}

According to Onyegu et al. (2012), the capacity of the conveyor is obtained using the formula:

$$
\mathrm{Q}=47 \mathrm{D}^{2} \operatorname{tn} \Psi \mathrm{ee}
$$

where:

$\mathrm{Q}=$ capacity of screw conveyor $(\mathrm{Kg} / \mathrm{hr}) ; \mathrm{T}=$ lead of screw conveyor $(\mathrm{m})$

$\mathrm{n}=$ expected speed of the screw conveyor $(\mathrm{rpm}) ; \mathrm{D}=$ diameter of screw conveyor $(\mathrm{m})$ 
$\Psi=$ capacity factor depending on the angle of inclination of the conveyor;

$\mathrm{E}=$ density of the materials $\left(\mathrm{kg} / \mathrm{m}^{3}\right)$

Using

$\mathrm{T}=0.66 \mathrm{~m} / \mathrm{s}$ as obtained from Eqn. (2), $\mathrm{N}=150 \mathrm{rpm}, \mathrm{V}=0.4, \mathrm{E}=450 \mathrm{~kg} / \mathrm{m}^{3}, \mathrm{C}=0.65$ at $20^{0}$

$$
\begin{aligned}
\mathrm{Q} & =(47)(0.1882)(0.66)(150)(0.4)(450)(0.65) \\
& =0.150 \mathrm{~kg} / \mathrm{hr}
\end{aligned}
$$

It implies that, continuously,the auger will convey $0.150 \mathrm{~kg} / \mathrm{hr}$ of the ingredients in one hour (Olaniyan \& Odewole, 2013).

\section{Determination of the Highest Rotational Speed of the Conveyor (Screw)}

According to Olaniyan and Odewole (2013), the highest rotational speed of the screw conveyor is obtained from the formula:

$\mathrm{N}_{\max }=\frac{A}{\sqrt{D}}$

where:

$\mathrm{N}_{\max }=$ highest allowable rotational speed (rpm); $\mathrm{A}=$ coefficient for light non-abrasive material; $\mathrm{D}=$ diameter of the screw $(\mathrm{m})$.

Using $\mathrm{A}=65$ and $\mathrm{D}=0.188 \mathrm{~m}$,

$$
\begin{aligned}
\mathrm{N}_{\max } & =\frac{65}{0.188} \\
& =149.9 \mathrm{rpm}
\end{aligned}
$$

Minimum rotational speed screw conveyor used in practice is obtained from the relationship ()

$$
\mathrm{N} \min =(20 \text { to } 30) \frac{1}{\sqrt{D}} \text { approx. }
$$

where: $\quad \mathrm{N}$ min $=$ minimum rotational speed of the screw conveyor $(\mathrm{rpm})$

$$
\mathrm{D}=\text { diameter of crew }(\mathrm{m})
$$

Using $\mathrm{D}=0.188 \mathrm{M}$,

$\mathrm{N} \min =20 \times \frac{1}{\sqrt{0.188 M}}=46.1 \mathrm{rpm}$. 


\section{Power of the Conveyor}

The power required by a vertical screw conveyor is divided into two:

- Power required to drive the conveyor empty

- Power required to lift the material through the designed height.

\section{Power Requirement to Drive the Conveyor Empty}

Power required to drive the conveyor empty can be taken to be the power required to drive the shaft. The shaft is a galvanized hollow steel pipe of external diameter $22.0 \mathrm{~mm}$ and internal diameter $20 \mathrm{~mm}, 1200 \mathrm{~mm}$ long. According to Culpin (1981), the power to drive the shaft is given by

$$
\mathrm{P}=\mathrm{TW}
$$

where:

$$
\mathrm{P}=\text { power }(\mathrm{W}) ; \mathrm{T}=\text { torque }(\mathrm{Nm}) ; \mathrm{W}=\text { angular velocity }(\mathrm{rev} / \mathrm{sec})
$$

Also, $\mathrm{T}=\frac{G \theta J}{L}$

where: $\mathrm{G}=$ modulus of rigidity $\left(\mathrm{N} / \mathrm{mm}^{2}\right), \Theta=$ angle of twist (rad); $\mathrm{L}=$ length of shaft $(\mathrm{mm})$

$$
\mathrm{J}=\text { polar moment of inertia }
$$

But $\mathrm{G}=83 \times 103 \mathrm{~N} / \mathrm{mm}^{2}$

$\mathrm{J}=\frac{\pi}{32}\left(\mathrm{D} 4 / 2-\mathrm{D}_{1}{ }^{4}\right)$

where: D2 = External diameter $(\mathrm{mm})$;

$\mathrm{D} 1$ = Internal diameter $(\mathrm{mm}) ;$

$\mathrm{J}=\frac{\pi}{23}(224$

$-204)=7290.06 \mathrm{~mm}^{4} ; \mathrm{T}=\frac{G \theta J}{L}, \Theta=1^{0}=0.01745 \mathrm{rad} . \mathrm{L}=1200$

$$
\mathrm{T}=\frac{(83 \times 103)(0.01745)(7290.06)}{1200}=8.7988 \mathrm{Nm}
$$

Angular velocity $(\mathrm{W})$ is given by $\mathrm{W}=\frac{2 \pi N}{60}$

$=15.707 \mathrm{rad} / \mathrm{s}$

$\therefore \mathrm{P}=\mathrm{TW}=(8.7988)(15.707)=138.21 \mathrm{~W}$ 


\section{Power Required to Lift the Material through the Designed Height}

The power is given by $\mathrm{N}_{\mathrm{vert}}=\frac{Q H}{367}$

where: $\mathrm{N}_{\text {vert }}=$ power $\mathrm{kW}$;

$$
\begin{aligned}
& \mathrm{H}=\text { height of the conveyor }(\mathrm{m}) \\
& \mathrm{D}=\text { capacity of the conveyor } \mathrm{kg} / \mathrm{hr} *=\frac{(19241.308)(1.2)}{367}=62.914 \mathrm{~kW}
\end{aligned}
$$

\section{Shaft Calculation}

\section{Determination of Torsional Stress}

The torsional stress,

$$
\mathrm{T}_{\mathrm{xy}}=\frac{M r R}{J}=\frac{G \theta R}{L}
$$

where:

$\mathrm{T}_{\mathrm{xy}}=$ torsional stress $\left(\mathrm{N} / \mathrm{mm}^{2}\right) ; \mathrm{Mt}=$ Torsional moment $\left(\mathrm{Nmm}^{2}\right)$;

$J=$ polar moment of inertia $(\mathrm{mm} 4) ; G=$ modulus of rigidity $\left(\mathrm{N} / \mathrm{mm}^{2}\right)$

$\Theta=$ angle of twist $(\mathrm{rad}) ; \mathrm{R}=$ radius of the shaft $(\mathrm{mm}) ; \mathrm{L}=$ length of the shaft $(\mathrm{mm})$

To calculate the maximum shearing stress,

$\Upsilon_{\max }=\frac{G \theta R}{L}$

where: $\mathrm{R}=10 \mathrm{~mm} \theta=180^{\circ}=1 \mathrm{rad} ; 1^{0}=\pi / 180-0.0174 \mathrm{rad}$

$\mathrm{G}=83 \times 103 \mathrm{~N} / \mathrm{mm}^{2} \mathrm{~L}=1200 \mathrm{~mm}$

$\therefore \Upsilon_{\max }=\frac{(183 \times 103)(0.0174)(10)}{120}=0.012 \mathrm{~N} / \mathrm{m}$

\section{Bearing Calculation}

\section{Bearing Selection}

From both standpoints of economics and simplicity of design, the single radial contact deep groove ball bearing is selected (used on the solid shaft), having the following dimension as chosen from the bearing catalogue (Dutchman, et al, 1975):

Bore diameter $=20 \mathrm{~mm}$; Outside diameter $=42 \mathrm{~mm} ;$ Width $=13 \mathrm{~mm}$ 


\section{Determination of bearing rating life (210)}

Assuming a life requirement of 6000 hours for form machinery's (Adusei-Bonsu et al., (2021), the number of revolutions $(\mathrm{N})$ is required for $95 \%$ reliability or $5 \%$ failure of the bearing would be:

$\mathrm{L} 10=6000$ hrs $\mathrm{x}$ shaft speed rpm

To convert to minute, $\mathrm{L} 10=6000 \mathrm{hrs} \times 60 \mathrm{~mm}=360,000 \mathrm{~min}$

Hence, $\mathrm{L} 10=360000 \times 150 \mathrm{rpm}=54000000 \mathrm{rpm}$

$\therefore \mathrm{L} 10=54 \times 10^{6} \mathrm{rpm}$

This implies that there is a possibility of bearing failure after $54 \times 10^{6} \mathrm{rpm}$.

\section{Belt Selection}

For this design, the V-belt drive is chosen for the belt drive. Conventional V-belts are made of rubber covered with rubber-impregnated canvas belts with dimensions (Olaniyan \& Odewole, 2013).

\section{Determination of Driver's Pulley Diameter}

A minimum ratio of the diameter of a pulley to the thickness of the belt is about 30 for reasonable life (Shiglry \& Mischike, 2001);

$$
\text { Hence, } \frac{D}{T}=30
$$

where: $\mathrm{D}=$ driven pulley diameter $(\mathrm{cm})$

$$
\mathrm{T}=\text { belt thickness or depth }(\mathrm{cm})
$$

From the equation (14) above, $\mathrm{D}=30 \mathrm{~T}=(30)(185)=555 \mathrm{~cm}$ or $0.55 \mathrm{~m}$.

\section{Determination of Transmissible Power}

$$
\mathrm{I}=\frac{n 1}{n 2}=\frac{d 2}{d 1}
$$

where: $\mathrm{n}_{1}=$ speed of driving pulley; $\mathrm{n}_{2}=$ speed of driven pulley

$$
\begin{aligned}
& \mathrm{d}_{1}=\text { diameter of driving pulley; } \mathrm{d}_{2}=\text { diameter of driven pulley } \\
& \mathrm{n}_{1}=1440 \mathrm{rpm} ; \mathrm{d}_{1}=55 \mathrm{~mm} ; \mathrm{n}_{2}=? \mathrm{~d}_{2}=185 \mathrm{~mm} \\
& \mathrm{I}=\frac{1440}{\mathrm{n} 2}=\frac{87}{55} ; \quad \mathrm{n}_{2}=\frac{1440 \times 55}{185}=428.4 \mathrm{rpm}
\end{aligned}
$$




\section{Determination of Maximum Transmissible Power}

According to Shigley and Mischke (2001), this is obtained using this formula below:

$$
\mathrm{P}=\frac{2 \pi n m}{60}
$$

where: $\mathrm{P}=$ maximum transmissible power, $(\mathrm{W})$

$$
\mathrm{n}=\text { shaft speed }(\mathrm{rpm}) ; \mathrm{m}=\text { shaft torque }(\mathrm{Nm})
$$

Using $\mathrm{n}=428.4 \mathrm{rpm} ; \mathrm{m}=8.7988 \mathrm{Nm}$

$$
\mathrm{P}=\frac{(2 n)(428.4)(8.7988)}{60}=394.73 \mathrm{~W}
$$

\section{Determination of Power Rating}

According to Shigley and Mischke (2001), this is obtained using the formula:

$$
\mathrm{P}_{1}=\frac{P}{C a}
$$

where: $\mathrm{P}_{1}=$ power rating of the drive (watts, $\mathrm{W}$ )

$$
\begin{gathered}
\mathrm{P}=\text { maximum transmissible power }=394.73 \mathrm{~W} \\
\mathrm{C}_{\mathrm{B}}=\text { Service factor }=1.8
\end{gathered}
$$

Hence, $\mathrm{P}_{1}=\frac{394.73}{1.8}=219.29 \mathrm{~W}$

\section{Determination of Belt Transmission}

The maximum belt tension is obtained using the formula:

$$
\mathrm{T}_{1}=\mathrm{S}_{\mathrm{m}} \mathrm{tb}
$$

where $\mathrm{T}_{1}=$ belt tension on the fight side $(\mathrm{N}) ; \mathrm{Sm}=$ recommended maximum best stress $\left(\mathrm{N} / \mathrm{m}^{2}\right)$

$$
\begin{aligned}
& \mathrm{T}=\text { belt thickness }(\mathrm{m}) ; \mathrm{B}=\text { belt width }(\mathrm{M}) \\
& \mathrm{Sm}=500 \mathrm{ps}(\text { for canvas belt })=(500 \times 6.895 \times 102)=3.4475 \times 105 \mathrm{~N} / \mathrm{m}^{2} \\
& \mathrm{~T}=0.87 \times 10^{-2} \mathrm{~m} ; \mathrm{B}=1.27 \times 10^{-2} \mathrm{~m}
\end{aligned}
$$

Hence, using equation 18 ,

$$
\mathrm{T}_{1}=(3.4475 \times 105)\left(0.87 \times 10^{-2}\right)(1.27 \times 10-20)=38.09 \mathrm{~N}
$$

\section{Centre Distance Determination of Shafts}

Recommended lower limit $\mathrm{e} \geq 0.7\left(\mathrm{~d}_{2}+\mathrm{d}_{1}\right)$

Using as calculated

$$
\mathrm{D}_{2}=185 \mathrm{~mm} ; \mathrm{D}_{1}=55 \mathrm{~mm}
$$


where: $\mathrm{D} 2=$ driven pulley diameter

$$
\mathrm{D}_{1}=\text { driving pulley diameter }
$$

It implies that

$$
\mathrm{e} \geq 0.7(185+55) ; \mathrm{e} \geq 168 \mathrm{~mm}
$$

Recommended higher limit,

$$
\begin{aligned}
& E \leq 2(d 2+d 1) \\
& E \leq 2(185+55) \leq 480 \mathrm{~mm} \text { (Rajput, 2006). }
\end{aligned}
$$

\section{Belt Length Determination}

According to Ear and Johnson (2007), this is obtained from the formula:

$$
\mathrm{L}=2 \mathrm{c}+1.57\left(\mathrm{~d}_{2}+\mathrm{d}_{1}\right)+\frac{(d 2+d 1) 2}{4 c}
$$

where: $\mathrm{L}=$ belt length $(\mathrm{mm}) ; \mathrm{d}_{2}=$ driven pulley diameter $(\mathrm{mm}) ; \quad \mathrm{d}_{1}=$ driving pulley diameter $(\mathrm{mm})$;

$\mathrm{C}=$ recommended minimum shaft centre distance $(\mathrm{mm}) ; \mathrm{D}_{2}=185 \mathrm{~mm} ; \mathrm{D}_{1}=55 \mathrm{~mm} ; \mathrm{C}=240$ $\mathrm{mm}$

$$
\text { Hence, } \mathrm{L}=2(240)+1.57(185+550)+(185+55)^{2} 4(240)=916.8 \mathrm{~mm}
$$

\section{Belt Speed Determination}

This is obtained using the formula:

$$
\mathrm{S}=\frac{d \times N}{19100}
$$

where: $\mathrm{S}=$ belt speed $(\mathrm{m} / \mathrm{s}) ; \mathrm{d}=$ diameter of driving pulley $(\mathrm{mm}) ; \mathrm{N}=$ speed of the driving pulley (rpm)

$$
\begin{aligned}
& \text { Using } \mathrm{d}=0.55 \mathrm{~m} \\
& \mathrm{~N}=1440 \mathrm{rpm} ; \quad \mathrm{S}=\frac{0.55 \times 1440}{19100}=0.0415 \mathrm{~m} / \mathrm{s} \text { (Feed-machine, 2021). }
\end{aligned}
$$

\section{RESULTS AND DISCUSSION \\ Performance Test of the Mixer}

The standard test procedures of ASAE S380 published in 2016 was used to test the mixer. After testing the machine empty, the actual evaluation was carried out. Locally available maize was used with rice bran, maize bran and groundfish as base materials ground to a fineness logarithm mean diameter of $0.251 \mathrm{~mm}$, logarithm mean standard deviation of 3.6 and moisture content of $15.25 \%$ (d.b). Feed materials for the test were loaded into the hopper and the machine was 
operated for the mixing operation. At time intervals of 2.0, 4.0, 6.0, 8.0 and 10.0 mins, samples were collected at the chute and later spread and the tracer materials-whole corn kernel, (WCK), coloured paper (CP) and Base materials (BM) - were manually picked. The whole kernel has a mean diameter of $4.90 \mathrm{~mm}$ while the colour papers were cut to a mean size of $5 \times 5$ $\mathrm{mm}^{2}$ (Kalu \& Chuwkuwonwe, 1986; Monison \& Monison, 1980).

\section{RESULTS}

Collected samples were spread and tracer materials were handpicked, weighed and percentage composition was calculated per sample and recorded, results obtained are as shown in Tables 1 and 2 below:

Table 1: Percentage composition of tracer per sample (for WCK and CP)

\begin{tabular}{llllllllllll}
\hline $\begin{array}{l}\text { Addictive } \\
\text { added (\%) }\end{array}$ & $\begin{array}{l}\text { Time } \\
\text { (mins) }\end{array}$ & \multicolumn{8}{c}{ Sample location and percentage of tracers in samples } \\
\cline { 2 - 13 } & 1 & 2 & 3 & 4 & 5 & 6 & 7 & 8 & 9 & 10 \\
\hline $5.0 \%$ WCK & 2 & 5.04 & 5.55 & 6.25 & 4.71 & 2.55 & 4.43 & 4.43 & 5.57 & 7.54 & 3.84 \\
& & & & & & & & & & & \\
$5.0 \%$ WCK & 4 & 5.55 & 6.25 & 6.09 & 6.16 & 7.84 & 4.84 & 5.38 & 7.24 & 5.00 & 7.98 \\
$5.0 \%$ WCK & 6 & 3.75 & 3.65 & 3.75 & 3.13 & 2.88 & 2.50 & 2.88 & 2.75 & 3.63 & 4.88 \\
$5.0 \%$ WCK & 8 & 2.54 & 1.92 & 2.29 & 2.53 & 1.80 & 1.73 & 1.95 & 2.01 & 2.38 & 2.03 \\
$5.0 \%$ WCK & 10 & 5.03 & 7.50 & 3.75 & 5.04 & 4.43 & 7.54 & 5.05 & 6.17 & 11.30 & 6.28 \\
$5.0 \%$ CP & 2 & 0.80 & 3.20 & 2.20 & 1.40 & 2.00 & 2.00 & 3.00 & 0.80 & 1.40 & 1.60 \\
$5.0 \%$ CP & 4 & 2.00 & 2.20 & 2.60 & 2.40 & 2.60 & 2.00 & 2.40 & 2.80 & 2.00 & 2.80 \\
$5.0 \%$ CP & 6 & 1.00 & 1.00 & 1.10 & 1.10 & 1.00 & 1.00 & 1.00 & 1.10 & 1.10 & 1.00 \\
$5.0 \%$ CP & 8 & 2.60 & 2.80 & 2.00 & 2.20 & 2.00 & 2.60 & 2.80 & 2.40 & 2.00 & 2.20 \\
$5.0 \%$ CP & 10 & 1.00 & 0.60 & 0.60 & 3.60 & 2.80 & 1.40 & 3.00 & 4.20 & 2.60 & 0.80 \\
\hline
\end{tabular}

Table 2: Calculated values of the mean $(x)$ and standard deviation $(\sigma)$ coefficient of variation (C.V) for WCK and CP

\begin{tabular}{|c|c|c|c|c|c|c|}
\hline $\begin{array}{l}\text { Tracer } \\
\text { material }\end{array}$ & $\begin{array}{l}\text { Time } \\
\text { (mins) }\end{array}$ & $\begin{array}{l}\text { No. of } \\
\text { samples (n) }\end{array}$ & $\begin{array}{lll}\text { Total value } & \text { of } \\
\text { samples } & \{\Sigma x\} & \end{array}$ & $\begin{array}{l}\text { Mean } \\
\text { value X] }\end{array}$ & $\begin{array}{l}\text { S.D } \\
\{\sigma\}\end{array}$ & $\mathrm{CV}$ \\
\hline WCK & 2 & 10 & 50.91 & 5.091 & 1.333 & 26.19 \\
\hline WCK & 4 & 10 & 61.18 & 6.118 & 1.064 & 17.39 \\
\hline WCK & 6 & 10 & 23.78 & 2.378 & 0.698 & 20.26 \\
\hline WCK & 8 & 10 & 21.18 & 2.118 & 0.295 & 13.95 \\
\hline WCK & 10 & 10 & 62.13 & 6.213 & 2.180 & 35.09 \\
\hline $\mathrm{CP}$ & 2 & 10 & 17.20 & 1.720 & 0.875 & 50.89 \\
\hline $\mathrm{CP}$ & 4 & 10 & 23.80 & 2.380 & 0.319 & 13.14 \\
\hline $\mathrm{CP}$ & 6 & 10 & 09.60 & 0.960 & 0.158 & 04.96 \\
\hline $\mathrm{CP}$ & 8 & 10 & 23.60 & 2.360 & 0.324 & 13.72 \\
\hline $\mathrm{CP}$ & 10 & 10 & 20.60 & 2.060 & 1.337 & 64.89 \\
\hline
\end{tabular}




\section{DISCUSSION}

The C.V is a measure of machine performance which was calculated as presented in Table 2 above. Higher variation was observed when WCK was used as a tracer compared with CP 1, I meaning that $\mathrm{CP}$ can easily mix with the base material. Generally, there was a considerable difference in the calculated C.V values for CP and WCK as tracers; this is because the WCK is coarser when compared with to $\mathrm{CP}$, resulting in the low values of the mix. Satisfactory mix values for both tracers occurred at 6 and 8 mins. Similar results were obtained by Balami et al. (2013), Olaniyan and Odewole (2013), and Adusei-Bonsu et al. (2021).

The modified feed mixer is illustrated in Plate 1 below:

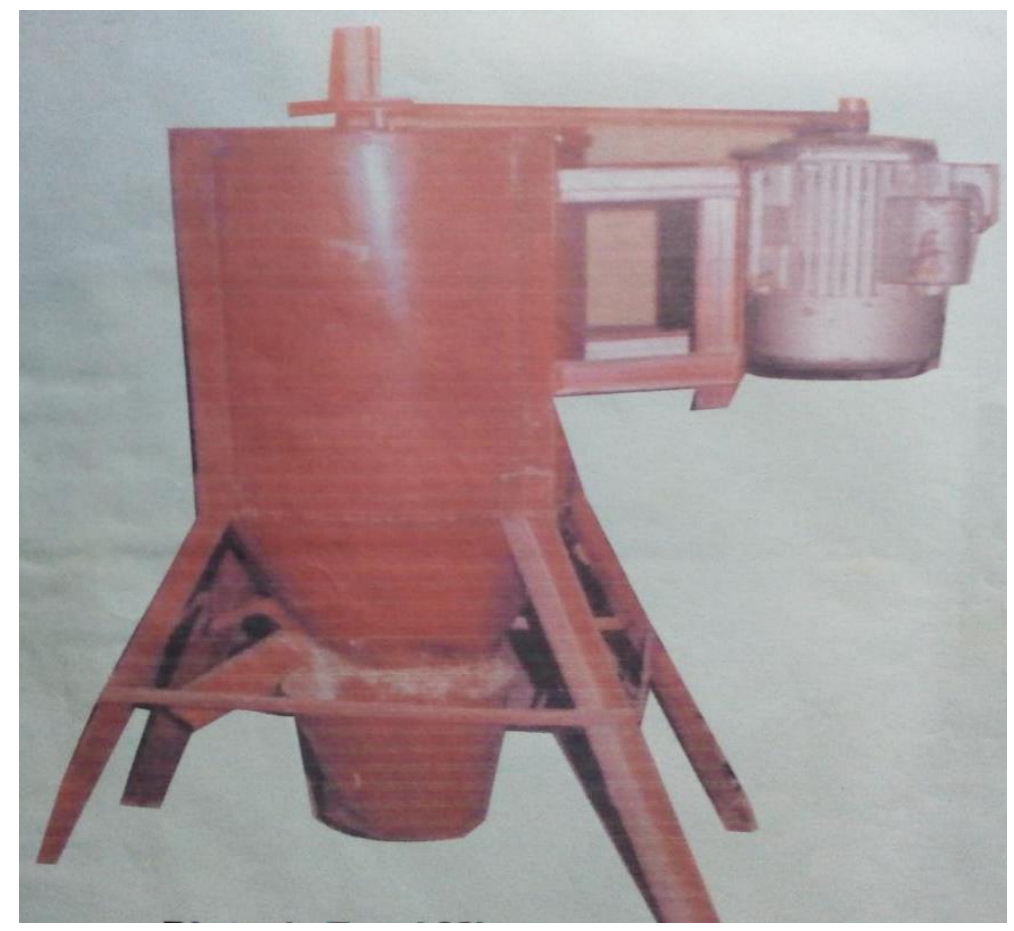

Plate 1: Modified feed mixer

\section{CONCLUSION AND RECOMMENDATIONS}

The motorized feed mixer has been modified and evaluated. Mixing valuestimes of 2, 4, 6, 8, and 10 mins were used to evaluate the machine. From the obtained results, a mixing time of 6 and 8 minutes gave the best mixing time for CP and WCK respectively. It was generally observed that the higher the size of the tracer, the lower the mixing efficiency.

\section{Recommendations}

1. Further tracers can be used to evaluate the machine.

2. Complete rations could be used for the evaluation.

3. The machine could be increased in order to increase the throughput capacity. 


\section{REFERENCES}

A. A. Balami, D. Adgidzi, and A. Mua'zu. (2013). Development Testing of an Animal Mixing Machine. International Journal of Basic and Applied Sciences. Insan Academic Publications. P-ISSN: 2302-4458; E-ISSN: 23018038, pp. 491-503.

A. Olaniyan and M. Odewole (2013). Design and development of livestock mixer with spring-controlled package unit. International Journal of Engineering Research in Africa. Tran tech publication, Switzerland. Pg. 43-55

A.A. Monison and L.A. Monison (1980). A Textbook of Animal Production, $4^{\text {th }}$ Ed. Oxford University Press, pp.40.

ASAE Standards, (ASAE S380 DEC1875 R2006), Test Procedures to Mixing Ability of Portable Farm Batch Mixers, pp. 261-262.

C. Culpin (1981). A Textbook of Material Handling Equipment. $2^{\text {nd }}$ Edition.

C.N. Kalu and A. E. Chuwkuwonwe. (1986). A Textbook of Food Compounding in the Tropics, $1^{\text {th }}$ Ed. Oxford University Press, pp.84-96.

Feed-machinery, Ensuring Optimum Mix-ability in Feed Manufacturing: Part 3-Factors that Affect Mixer Performance, https://www.feedmachinery.com/articles/feed_technology/mixiability3/; (accessed October 2021) 2021.

H. A. Dogo. (2001). The effect of different levels of palm cake on performance and carcass characteristics of broiler chickens. Proc. $6^{\text {th }}$ Annual Animal Sc. Association of Nigeria 17-19 Sept. 2001. pp.49.

J. A. Akpobi, and G. C. Ovuworie. (2008). Computer-Aided of the Critical Speed Shafts, Journal of Applied Science and Environmental Management, pp, 79-86.

J.F. Shiglry, C. E. Mischike. (2001). Mechanical Engineering Design. McGraw Hill Book Company New York.

M. Adusei-Bonsu, I. N. Amanor, G. Y. Obeg and E. Mensah. (2021). Performance evaluation of mechanical feed mixers using machine parameters, operational parameters and feed characteristics in Ashanti and Brong-Ahafo regions, Ghana. Alexendris Engineering Journal, 60, 4905-4918. www.elsevier.com

M. J. Asunda. (2003). Modification of a portable powered feed mixer. An Unpublished Thesis submitted in the Department of Agricultural and Bio-Environmental Engineering Technology, Federal Polytechnic, Bauchi.

N. N. Agbor. (1996). Design and construction of a portable feed mixer. An Unpublished Thesis submitted in the Department of Agricultural and Bio-Environmental Engineering Technology, Federal Polytechnic, Bauchi.

O. S. Onyegu, O. Ibifuro, N. Idung, and T. Aguheva. (2012). Design and fabrication of an Industrial Poultry Feed Tumble Mixer. Leonardo Electronic Journal of Practices and Technologies. ISSN 1583-1078, pp. 49-60.

R. K. Rajput. (2006). Strength of Materials, $4^{\text {th }}$ Ed. S. Chand and Company Ltd., New Delhi.

R. S. Klarmi and J.K. Gupta. (2005) A Textbook of Machine Design, $14^{\text {th }}$ Ed., S. Chand and Company Lit., New Delhi.

S. S. Diarra, I. D. Kwari and H. D. Kwari (2001). Effect of substituting wheat brain with millet bran nutrients digestibility and intestinal morphology of broiler chickens. Proc.

$6^{\text {th }}$ Annual Animal Sc. Association of Nigeria, 17-19 Sept. 2001. pp.64.

T.S. Ear, and B.P. Johnson. (2007). Production engineering. $3^{\text {rd }}$ Ed. Tata Mcgraw Hill Company Ltd., New Delhi. 